\title{
CONTROVERSIES AND TRANSITIONS FOR SUSTAINABLE DEVELOPMENT
}

https://doi.org/10.4215/rm2020.e19027

\author{
Neli de Mello Théry $\mathrm{a}^{*}$ - Patrick Caron $\mathrm{b}$
}

(a) PhD in Geography. Professor at the University of São Paulo, São Paulo (SP), Brazil.

ORCID: http://orcid.org/0000-0003-2313-2121. LATTES: http://lattes.cnpq.br/1210499203186406.

(b) Doutor em Fitotecnia. Prof. Pontifícia Universidade Católica de Goiás, Goiânia (GO), Brasil

ORCID: http://orcid.org/0000-0002-8494-2243. LATTES: https://muse.edu.umontpellier.fr/en/2019/10/07/patrick-caron/.

\author{
Article history: \\ Received 30 August, 2020 \\ Accepted 10 September, 2020 \\ Publisher 15 November, 2020
}

(*) CORRESPONDING AUTHOR

Address: Rua Albuquerque Lins, 1169 apto 231B. 01230-001 Santa Cecilia, Sao Paulo (SP), Brasil. Phone: 1186595380.

E-mail: namello@usp.br

\begin{abstract}
Science does not progress without controversy as well the societies. In this article, this approach is privileged, aiming to analyze whether they can hinder or speed up the agricultural and food, environmental and sanitary transitions necessary to achieve the Sustainable Development Goals (SDGs). It begins with an alert to the past development model and the limits of the planet, highlighting some themes and forms of action chosen by international institutions and / or scientist's networks. Then, we selected some controversies and their arguments, related to environmental issues and the evolution of food systems. In the subsequent item, its actors and five sub controversies sought to highlight the difficulties for the transition to circular systems, considered as a vector of sustainability. It is concluded that controversies can block advances for transitions, being essential the design of methods, criteria and indicators for a better understanding of oppositions, as well as the need to include both themes and new approaches in research agendas.
\end{abstract}

Keywords: Development Goals, Environmental Issues, Food Systems, Research Agendas.

\section{Resumo / Résumé}

\section{CONTROVÉRSIAS E TRANSIÇÕES PARA O DESENVOLVIMENTO SUSTENTÁVEL}

A ciência não progride sem controvérsias assim como as sociedades. Nesse artigo privilegia-se esta abordagem, visando analisar se as mesmas podem entravar ou agilizar as transições agrícolas e alimentares, ambientais e sanitárias necessárias à realização dos Objetivos do Desenvolvimento Sustentável (ODS). Inicia-se com um alerta para o modelo de desenvolvimento passado e os limites do planeta, destacando alguns temas e formas de atuação escolhidas por instituições internacionais e/ou redes de cientistas. No segundo momento, selecionamos algumas controvérsias e seus argumentos, relacionadas à questões ambientais e a evolução dos sistemas alimentares. No item subsequente, seus atores e por meio de cinco subcontrovérsias procurou-se destacar as dificuldades para a transição aos sistemas circulares, considerados como vetor de sustentabilidade. Conclui-se que polêmicas relacionadas com estas controversas podem bloquear os avanços para as transições, sendo essencial a concepção de métodos, critérios e indicadores para melhor compreensão das oposições, bem como a necessidade de inclusão tanto de temas como de abordagens novas em agendas de pesquisas.

Palavras-chave: Desenvolvimento Sustentável, Questões Ambientais, Sistemas Alimentares, Agendas De Pesquisas.

\section{CONTROVERSES ET TRANSITIONS POUR LE DÉVELOPPEMENT DURABLE}

La science ne progresse pas sans controverse comme le font les sociétés. Dans cet article, cette approche est privilégiée, visant à analyser si elles peuvent freiner ou accélérer les transitions agricoles et alimentaires, environnementales et sanitaires nécessaires pour atteindre les Objectifs de Développement Durable (ODD). Il débute par une alerte sur le modèle de développement passé et les limites de la planète, mettant en évidence certains thèmes et formes d'action choisis par les institutions internationales et / ou les réseaux scientifiques. Au deuxième item, nous avons sélectionné quelques controverses et leurs arguments, liés aux enjeux environnementaux et à l'évolution des systèmes alimentaires. Après, l'analyse de quelques acteurs et de cinq sous-controverses ont mettre en évidence les difficultés pour la transition vers des systèmes circulaires, considérés comme un vecteur de durabilité. Les conclusions sont que les controverses peuvent bloquer les avancées pour les transitions, étant essentiel la conception de méthodes, de critères et d'indicateurs pour une meilleure compréhension des oppositions, ainsi que la nécessité d'inclure à la fois des thèmes et de nouvelles approches dans les programmes de recherche.

Mots-clés: Développement Durable, Enjeux Environnementaux, Systèmes Alimentaires, Programmes De Recherche. 


\section{INTRODUCTION}

Since the recognition of the global nature of the environmental crisis, there have been several attempts at negotiation within the United Nations. Each of the world conferences that discussed issues linked to the relationship between the environment and development models (1972, 1992, 2002, 2012), made advances due to the warnings by scientists about the dangers to the planet and societies and by the political engagement of many countries, resulting in agreements, conventions, and protocols. In all of these, proposals and agendas were agreed by the member countries of the UN system.

However, national governments have always fallen far short of the organizers' intentions regarding the concrete implementation of actions that would represent paradigm shifts. The thresholds pointed out in each instrument were supported by existing knowledge, but they have always been exceeded. Although the initiatives of previous conferences, such as Agenda XXI or the Millennium Goals, addressed ways of transitioning from one model to another, the focus was not on the transitions per se. This term and concepts were developed at the beginning of this century and are applied particularly in the public management of the environment, industry, and energy policies of the Netherlands Ministry of Economic Affairs (René Kemp and Derk Loorbach, 2002).

In the same period, the Johannesburg Summit proposed that the world transition from the traditional economy to a green economy, indicating the possibility of changing the form of exploitation, but it lacked an understanding of the main axes, limits, and scope of this change (CGEE, 2012).

Unlike the case of the concept of sustainable development, there were almost no debates. There was none of the preparation needed for the concept presented by the United Nations to circulate in the world at large and win over hearts and minds, to achieve a minimal reach in the international debate. There was not even any consensus on the opportunity to displace the concept of sustainable development in favor of the green economy (the Stern Report, coordinated by Sir Nicholas Stern, a British economist at the World Bank, was commissioned by the British government to ascertain the effects on changes in the world economy over the next 50 years). The purpose seemed to be to isolate the economic dimension of the problem, especially in the perception of developing countries.

Also in 2000, the United Nations Millennium Cupula defined eight objectives, known as the Millennium Goals, focused on the issues of poverty, primary education, gender equality, health, environmental sustainability, and global partnership for development, which should be reached by 2015 .

In 2015, world leaders pledged to tackle the most urgent global problems with a new agreement, Agenda 2030, reorganizing and transforming previous issues into 17 Sustainable Development Goals, regarded as transitional elements to a sustainable world. These objectives sometimes contradicted each other and failed to show the paths to be followed. They reinforced the need for environmental, health, agricultural, and food transitions to occur so that they could be achieved. However, all these themes are the subject of controversial debates and usually antagonistic positions.

\footnotetext{
The red warning light came on when the worldwide demographic data pointed to the issue of food insecurity and the inability to feed the world population, with all the regions of the planet at risk. At the global level, the High-level Political Forum on Sustainable Development (HLPF) was established to monitor the implementation of the Agenda. Since 2017, its themes have sought to integrate the issues of food, health, and the environment by choosing sub-themes such as Eradicating poverty and promoting prosperity in a changing world (HLPF, 2017), Transformation for a sustainable and resilient society (HLPF, 2018), and Empowering people and ensuring inclusiveness and equality (HLPF, 2019)
}

From the perspective of political ecology, ecological transition theories seek ways to align development models with sustainable development, focusing on management, perception, access, and the conflicting appropriation of territories and resources. These theories are divided into two strands. The responsible and sustainable use of natural resources aims to determine the foundations of future policies, using a multicriteria analysis of the energy and resource exploitation sectors. Secondly,.biodiversity management (uses of biodiversity resources, ecosystem services, payments for 
environmental services or sustainable solutions inspired by nature) requires the knowledge of specific compositions, ecological dynamics, weather conditions and the evolutions caused by climate change.

These approaches include the notion of resilience and social justice, which implies understanding how societies will behave to anticipate changes, in terms of the adaptations required, and mitigation, adaptation, and resource use strategies.

The conventions agreed in 1992 by the UN dealt with transversal environmental issues such as biodiversity, climate change, and, in 1994, desertification. The UN highlights that for the next few years the most relevant issues are climate change, environmental refugees, cities, plastic pollution, the vulnerability of wild animals, and the risks to coral reefs. If ecological transition implies being able to "manage the use of soil, water, and ecosystem services", it is important to know the effects of agricultural production and food security on these issues. For example, changing from rural to urban land use reduces areas for agricultural production. Pollution by plastics and pesticides used in agriculture have impacts on oceanic and terrestrial life, while climate variability and change affect plants and animals. The probable solutions are the origin of sociotechnical controversies. Among other factors, solutions depend on scientific knowledge and technological innovations.

Global reports also present balance sheets and forecasts for the year 2050, involving several sub-sectors, among which we highlight biodiversity, water, and ecosystem services. According to PNAS (2015), reducing meat consumption may prevent the loss of $60 \%$ of biodiversity by 2050 . Meat and grain production uses 15,500 liters of water per kilogram of meat while cereals only use 1,600 liters. Agriculture produces 25 times more proteins than livestock in an area 2.6 times smaller than pastures; and agroecology may save cultural food diversity. These reports also analyze land use, pointing out that only $25 \%$ of the world's agricultural land produces the cereals and vegetables that directly feed the human population, whereas one-third of the world's land is used for pasture and another third is used to grow cereals for animal feed. Feeding a person whose diet includes meat requires an area three times larger than that needed for vegetarians.

Thus, the food issue is included in some of the SDGs, and scientists are working on the prospects for the world food system. They question the permanence and maintenance of the agro-industrial model and whether proximity models would be better for human and environmental health (Jean-Louis Rastoin, Gérard Ghersi, 2010). The comparison between conventional and organic production made by Reganold and Wachter (2016) illustrates the best equilibrium in the agricultural, environmental, social, and economic areas of sustainability and indicates organic production as the best balance. Similarly, many authors point to agroecology as an option to reach the SDGs (HLPE, 2019). Some analyze theories on the circularity of the economy for the sustainability of the food system (Alexandra Jurgilevich et al., 2016), promoting circular food systems as an option for sustainable development (De Boer and Van Ittersum, 2018). However, implementing such proposals raises many questions. For example, the complexity of the question "on what scale should the circular food system be organized, local or global?" points to issues related to five SDGs: 2 - the eradication of hunger; 3 - quality health care; 13 action against global climate change; 14- life in the water and 15 - terrestrial life.

\section{CONTROVERSIES}

A controversy is a divergent and usually conflicting position between opposing groups regarding a theory, or the historical or philosophical facts associated with it (Chevallier-Le Guyader and Girel, 2015). During the process, for a time the controversy may be confined to the academic world (Lemieux, 2015). An alternative approach, known as socio-technical controversies, which focuses on modern technologies and their use in society, is currently being disseminated by authors such as Bruno Latour (1987), Michel Callon (1986), Pierre Lascoumes and Tommaso Venturini in France, and Ricardo Abramovay in Brazil. At MAK!T (https://muse.edu.umontpellier.fr/international/makeit/), the main hypothesis is that dealing with oppositions through the analysis and organization of controversies can facilitate the understanding of the obstacles faced in the transition to sustainable development, thus, speeding up the process. The theme of the circular system was chosen as a pilot controversy to test this hypothesis through interdisciplinary analysis and debate.

A circular food system involves changing paradigms and development models and rethinking how 
foodstuffs are produced and consumed (De Boer et Van Ittersum, 2018). Consequently, the proposal aims to transform linear production systems, characterized by the lack of attention to the renewal of natural resources and ecological externalities of production into circular systems (see Box 1). Due to its advantages, in principle, this proposal does not face any opposition, aside from those who cannot continue to take advantage of extraction. It reflects the unfeasibility of the durability and sustainability of the linear system, due to the environmental costs it represents, its use of resources, pollution from chemical fertilizers and pesticides, the excessive use of water or the exploitation of resource-intensive products, the widespread production of waste, the need for storage, energy and transport infrastructure, and especially, the loss of food, which are all essential elements of a global food circulation model for the world population. In August 2018, the linear production model reached the limit of the planet's natural recovery.

Rather than analyzing agriculture itself, we are interested in food production through a circular system as opposed to the linear, conventional system. In general, the conventional model of agricultural development considers that increased productivity results from the specialization of livestock and agriculture, which should be separated regardless of their effects on the environment. A circular feeding system values both the interactions between animal and plant production and the positive effects for the environment, not just negative ones.

The first cohort agreed for the creation of MAK'IT focused on the minimum use of finite natural resources, such as land, as well as the circular use of all natural resources. This approach aims to contribute to improving the nutrient cycle, ensuring its availability, and preventing unwanted environmental effects, in particular through an appropriate mobilization of the role of animals.

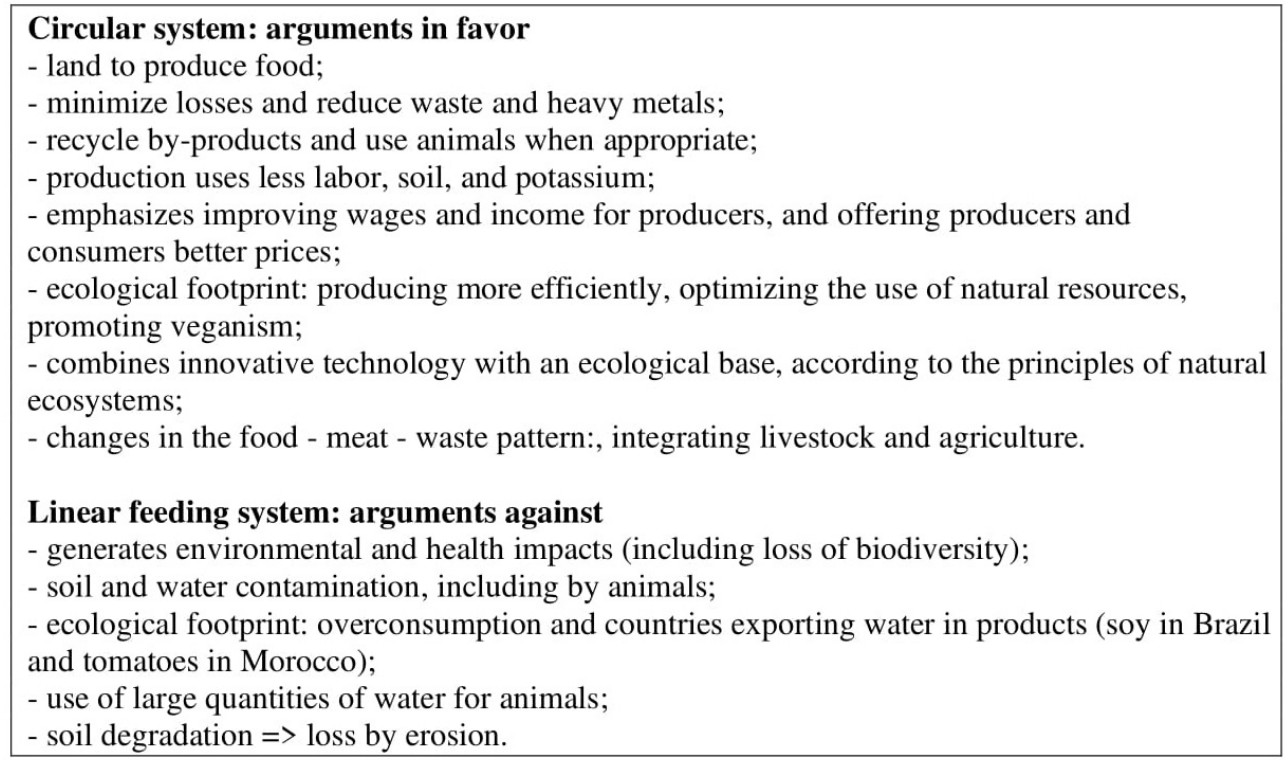

Box 1 - Main characteristics of circular and linear food systems.

Changes in the paradigms and models from the past face challenges and find limits both on a global and local scale. Therefore, the question of defining a local or global scale to develop a circular system is pertinent and raises many issues, often leading to many different positions being adopted.

On the global scale, typified by long circuits, the process is mainly linear and does not consider interactions within food systems. Instead it aims at accumulation through the expansion and optimization of commodity production. In recent years, these circuits have proved extremely dependent on chemicals to fight diseases. Although large-scale production may reduce costs, the circulation of these products depends on industrial logistics, such as good infrastructure for roads, ports, and storage, but reducing food losses in the different stages from the producer to the consumer is the great challenge and requires specific policies, control over the different phases, and changes in the behavior of decision-makers and society. 
The local scale, especially in short circuits, is rich in diversified experiences and initiatives, including organic and biological production, the recovery of food cultures with specific products, permaculture, and the exploitation of local biodiversity. However, products must often be consumed in a short period, and may also have higher production costs This model does not permit the necessary regulation of prices or international and national competition and can promote even tougher competition among local producers.

The interests of the actors in these two circuits also differ. Industrialized food giants manage to sell their products to different markets. Despite its worldwide circulation, their food is cheaper and more accessible, but often to the detriment of its quality and the remuneration of producers. Recently, many of these companies have started implementing social and environmental responsibility programs, exploring opportunities in specific chains and/or to guarantee a "sustainable" image without necessarily changing their production model.

Feeding ten billion people by 2050 within planetary limits may be achievable, but it requires a global shift toward healthy, plant-based diets (Willett et al., 2019), halving food loss and waste, according to researchers at the Stockholm Resilience Center.

This awareness increasingly points to the development of local experiences (See Box 2), which are capable of profound changes and have already been implemented in several places. Nevertheless, strong and agile global coordination is required to show a significant impact beyond the location where these practices are being implemented without repercussions on a global scale. The sum of successful local projects is not sufficient to bring about profound global changes, although they can undoubtedly serve as a basis for the process of transition to sustainability. At the same time, comprehensive international policies and agreements are needed to achieve this impact and make new local initiatives possible.

Numerous local experiences have developed in different countries in Asia, Africa, and Latin America. Known as sustainable production or local ecological revolutions, many projects value ancestral knowledge to face the challenges of the future. There are thousands of "peaceful revolutions", which have been in place for about 20 - 30 years. They include the restoration of ecosystems with the maintenance of humidity, selfsufficiency, and the right to water in arid areas, actions favoring public management, rain harvesting experiences, and the recovery of native seeds for revegetation or food production.

Cities have become a new agricultural frontier due to the vulnerabilities to which the urban population is subjected. In resilient or sustainable cities, agricultural neighborhoods and districts, hanging gardens, and urban farms have multiplied. The FAO (2006) reports that 800 million urban dwellers produce 15 to $20 \%$ of the world's food, occupying about 456 million hectares, an area almost the size of the European Union. Cities like New York, Paris and many industrialized countries have converted public spaces into vegetable gardens aiming at food autonomy and social inclusion. According to the Lawrence Berkeley Institute Laboratory, examples of roof vegetation also contribute to the fight against global warming and become spaces of resilience. In Brazil, after the 1992 Rio-CNUMAD Conference, the Pilot Program for the Conservation of Tropical Forests, PPG7, an important multilateral project, was implemented, of which we highlight the Amazon demonstration project. In the almost twenty years since it was established it has financed community projects, associations, small municipal governments, and non-governmental organizations. Support included the themes of combating deforestation, protecting traditional peoples, and new forms of production with social participation. The results of the final balance were: 447 projects supported, more than 350 non-governmental organizations strengthened, 40 thousand people trained, 34 conservation units supported, and 77.2 million euros invested.

Box 2. Local experiences in the development of sustainable agriculture. 
The co-existence between different views of agriculture and its contribution to sustainable development is evident. However, the time scales of 20-30 years needed to implement profound changes, demand strategies of involvement and performance. On the one hand, they should stimulate large producers and distributors to change more quickly, and, on the other, stimulate society to value local experiences so that they serve as models for actions in other places. Given that the consolidation of experiences depends on longer timeframes, increased investment in human and financial resources can speed up their influence and replication. This demonstrates the need to define different but interconnected and coherent strategies for the local, national, and international scales.

\title{
THE ENVIRONMENT AND CONTROVERSIES RELATED TO THE EVOLUTION OF CIRCULAR FOOD SYSTEMS
}

Environmental issues related to agriculture almost always concern negative impacts, which hinder the transition to sustainable development. Given the complexity of the interactions between these two areas there are many uncertainties regarding the real effects. Like the positive effects, some of the negative effects are already proven, but not all of them. These uncertainties stem from a lack of scientific and/or technological knowledge and make decision-making difficult, due to the instability they represent, the heterogeneity of actors, and the objections and discussions between two intransigent sides.

Firstly, we address the negative effects of food production, of which one of the most important is land use because in most cases the conversion of ecosystems into agricultural land leads to an increase in $\mathrm{CO}^{2}$ emissions, eutrophication, and the loss of productivity, energy and natural resources.

\begin{abstract}
This process results from the need to expand to new areas in tropical forest ecosystems or to intensify agricultural production, based on the use of fertilizers and pesticides. In some countries, even though there is awareness of the impacts of converting ecosystems into agricultural areas, this process continues. There is also awareness of the need to change eating habits, which has led to different strategies and policies being established, such as taxes on foods of animal origin. The animal production industry is among the greatest consumers of natural and man-made resources(FAO, 2006; SVB, 2015).
\end{abstract}

These facts trigger different opinions in the most diverse fields of knowledge as well as in sectors of society. Although the arguments for and against are understood, both sides of these socio-scientific controversies keep their positions unchanged and hinder the search for the third way, seen by Sachs (2008) as a solution that prevents the ecological-economic dilemma being reduced to a bland syncretism, from the change in contemporary society's patterns of production and consumption .

For this reason, we are interested in understanding the controversies about the proposal for circular food systems because this would enable a better identification of the difficulties and reasons that the actors face and block the transitions to sustainable development.

\section{CONTROVERSY MAPPING}

Considering the arguments above, and to be able to synthesize the debates related to the circular food system, the multiple divergences must be considered.

As for the scale for the circular system, Hall (2002) states that globalization has allowed local identities to be salvaged and strengthened, suggesting that it would be most suitable to think about a new articulation between these two categories.

The impact of local systems, known as the locavore movement (Azevedo, 2015), on the environment, economy and society is one of these divergences. Some argue that these food systems are more efficient because of the importance of distance in determining the environmental impacts of transport. Another factor is the preservation of the genetic diversity of food species and the promotion of environmental quality as local properties are also living spaces for farmers who have their ecological 
rationale, which adjusts to the complexity of the rural environment and maintains their cultural identity.

However, the possibility of rescuing local foods and regions should not interfere in relationships with other cultures, through access to and consumption of exotic dishes and cuisines. The entry of exogenous foods brings cultural hybridity, opportunities, and the acceptance of differences.

Conversely, long-distance chains make it possible to anticipate food shortages in a given region, supply cities, regulate prices, and avoid excessive volatility. In this context, local, regional, or international characteristics and specificities should be valued, taking into account their positive and negative contributions to sustainable development.

If the two categories are to co-exist and coordinate better to construct new attitudes and act as consolidating policies, it is important to identify how the global and local actors in the controversies are positioned and will progress towards transition and how arguments for and against block transitions, or not.

\section{DIFFICULTIES IN ENSURING A TRANSITION TO CIRCULAR SYSTEMS}

There are five controversial aspects in the analysis of the potential for transition to sustainable systems, the differing perceptions of which make the transitions slow and difficult.

\section{DIET AND FOOD CONSUMPTION AT THE CENTER OF DIVERGENCIES}

Diet is a transversal vector that cuts across different development conditions and has become extremely important in recent debates. Some scientists and social groups are in favor of changing current consumption patterns and endorse the emergence of vegetarianism, veganism, and the locavore movement, among other possibilities.

Different groups support dietary choices that conserve biodiversity, either because local biodiversity offers new products that can be included in the diet, or due to the positive effects of production systems, which can offer environmental services and anticipate risks of degradation. For example, International research centers, such as the Stockholm Resilience Center, Global Resilience Alliance, and Bioversity International, argue that the interactions between animals, crops, trees, and microorganisms make it possible to provide food and fiber using less fuel, consuming less water, and supporting ecosystem services. These groups promote and value local communities, who are also highly active actors, and their products.

Another intense discussion relates to water use and the water footprint in industrialized animal production (SORDI, 2013). Although $70 \%$ of the water used in the world is spent on agriculture, estimates indicate that at least one-third of the total water used on the planet is destined for livestock, for drinking, and the often distant production of forage and animal feed (HEINRICH BÖLL FOUNDATION, 2015). Also, eating habits based on the increase in global meat consumption produce cascading effects, creating the need to increase food production for cattle competing with human food supplies (FAO, 2006, Mottet et al., 2017). As a result, the reduced consumption or exclusion of locally produced or imported meat, and the increased intake of vegetable products has gained many followers.

The excessive consumption of meat, especially beef, has known effects on human health, particularly due to the increasing prevalence of obesity (HLPE, 2016). These impacts can occur at a distance due to global-local connections, when producing countries like Brazil export meat (Théry and Caron, 2019) or grains (soy and corn), despite the different externalities resulting from their production.

The actors involved in this debate are found at national and international levels. Primarily, these positions are supported by conservation-oriented non-governmental organizations, national and international researchers and research centers, scientific journals (Elsevier, NPJ-Nature partner journals), and panels of international experts (HLPE, 2016). 
The television and print media, such as The Guardian and the BBC have increasingly shown support for the idea, promoting campaigns, spreading experiences, and relating food to diseases, often creating recipes for the better use of products. Social networks also disseminate alternative recipe books with products aimed at reducing environmental footprints.

\section{LAND USE}

In the context of the rising world population and anguish over food shortages, the discussion on land use for agricultural production is marked by the co-existence of two confronting approaches. Land sparing involves dividing land into areas without agricultural production, dedicated to the protection of biodiversity, and agricultural land, with intensified production. However, land sharing aims at ecological production through sharing land and promoting these services in agricultural environments.

The arguments in favor of adopting land sparing as the most promising strategy for the environment are that through land preservation, ecosystems' internal conditions would be better maintained by confining agriculture and ecosystems to specific areas, in a form of zoning. On the contrary, defenders of land sharing state that, except for rare cases in which exotic species collapse, conservationists should embrace these agroecosystems, rather than avoiding them, as they are important sources of ecosystem services including forest products and rich in both native and exotic biodiversity.

Analyzing different global experiences and the arguments for or against the two options, the HLPE (2019) concludes that "there is no single universal answer to this debate, which originated from questions raised at the global level to address agriculture-driven deforestation- and environment-related concerns. At the local level, avenues to address such concerns, including mixed arrangements, and their impact may vary according to specific biological, ecological and institutional context".

\section{INDUSTRIAL CONCENTRATION IN THE AGRICULTURAL SECTOR}

Agribusiness is one of the important sectors of the world economy, although production and transformation are concentrated in certain countries. The livestock sector illustrates the conflicts. It is noteworthy that the ten largest chicken meat production companies (slaughter volume) are concentrated in only six countries (three in the USA, two in Brazil, two in China, and one each in Mexico, Thailand, and Saudi Arabia) and are essential for their economies. While in many OECD countries there is a growing awareness of the need to reduce the consumption of animal products, the role of industrial livestock in these countries is an additional controversy. The arguments supporting these debates are based on the socio-economic benefits that animal production brings to the countries' development by contributing to the GNP, generating jobs in sectors complementary to production, encouraging the creation of new industrial sectors and technologies. The agro-industrial sector is usually defended nationally and internationally by large-scale producers, politicians interested in or from these sectors, large distributors (supermarkets, etc.), and processed food companies, in business forums like Davos and multilateral negotiations.

The problems generated by agro-industrial concentration do not only affect the animal production sector, most of the agricultural chains are also similarly impacted (Murphy et al., 2012). The bulk of food is being produced in less than ten countries, generating risks of food insecurity (HLPE, 2017) and sustainability. In addition, this concentration appears to be a factor blocking many transformations, due to conflicts of interest, difficulties in revisiting the rules of international trade or oppositions between dual visions of the future.

\section{AGRICULTURE'S ENVIRONMENTAL FOOTPRINT}

Unlike the sometimes controversial water footprint, indicators have not been created for the agricultural footprint yet. The role played by agriculture and livestock in the degradation of soils and water resources, in global warming through deforestation and methane production, in threats to biodiversity and climate change is undeniable. These impacts are especially cited when discussing alternative diets. 
The conversion of areas of natural vegetation to monocultures and pastures results in deforestation, often accompanied by the use of fire. Depending on climatic conditions these burnings can turn into conflagrations that affect much larger areas than those initially intended to be converted into agricultural land. Similarly, the increase in pasture areas means rises in the number of cattle, which contributes to methane emissions and, consequently, climate change. Given that land-use conversion takes place in spaces with high biodiversity, the loss of these ecosystems, about which often little is known, is increasing.

Deforestation is one of the foremost arguments put forward by the actors who defend changes in land use patterns, especially in tropical forests such as the Amazon, since the highest rates occur in this region . In 2018, Brazil and Indonesia accounted for 46\% of tropical forest deforestation worldwide (Global Forest Watch).

Various studies apply the water footprint method to certain agricultural and agro-industrial products. The product's life cycle or production process is considered based on information related to the amount of water needed. This serves to assess potential environmental impacts caused by water use in different regions and point out the risk of scarcity.

The issues involved in assessing and comparing the agricultural footprints of different locations translate into oppositions and controversies, making transitions difficult.

\section{SHORT-DISTANCE VERSUS LONG-DISTANCE CHAINS}

Short chains are often considered to be more sustainable and are being promoted more frequently, aiming to reduce the footprint linked to transport, counteract the power of large industries, supply better quality products based on trust between producers and consumers, and promote changes in eating patterns and alternative diets. Supporters of short circuits argue that encouraging production and consumption in local markets can reduce the need for long-distance transport, reducing the consumption of oil products and their contribution to global warming. They are opposed by players in the large food industries and producers who are in favor of maintaining global markets, and imports and exports of industrialized foods, which can retain lower prices.

Many diverse short-circuit, local production, and trade initiatives experienced by alternative associations and communities can be identified and signaled around the world, according to Bénédicte Manier's book Un million de révolutions tranquilles. Experiences in allocating part of exported products to local markets and replacing imported goods with others of local origin are being encouraged. Given the reputation for better quality, cities are increasingly concerned with closer supply chains. These changes may be a paradigm shift in the current model and many actors are taking initiatives in this direction. The COVID 19 crisis has intensified this movement (Caron, 2020), although by necessity rather than choice.

Acting in partnership, non-governmental organizations (Conservation International, Honey Bee Health Coalition, National Fish and Wildlife Foundation), universities, and local governments have formed international networks to develop new paradigms and new experiences, as demonstrated by the Milan Pact Awards. Furthermore, multinational companies and agro-industries, have also invested in corporate social responsibility and advocated actions to protect, conserve, and restore biodiversity, developing new products, through novel partnerships to maintain productive farms without threatening species.

However, few policies encourage short-term food circulation and these experiences rarely go beyond the local or regional scale. For example, only $5 \%$ of farmers in the USA are involved in these transitions.

Therefore, these local or regional changes are not yet able to consolidate on a global scale, due to the type of products, the small number of producers and consumers, and higher prices compared to agro-industrial production. Other factors include the lack of consensus and support at the public policy level.

Owing to growing demand and the number of adherents, there is a rise in public policy initiatives aimed at supporting transitions to short-distance food supplies, such as national institutions or local collectives in Europe and Brazil. These policies define new markets, implement incentives, and organize 
research to support their advantages. Changes can only result from a coherent articulation of local initiatives, public policies, and international regulatory frameworks.

\section{CONCLUSION}

The barriers and oppositions identified herein lead to the conclusion that they act to hinder decision making to invest in the actions of agricultural, environmental, and health transitions foreseen in the Sustainable Development Goals. There will always be reasons for postponement, even if they are inadequate. The example of sustainable food systems shows how alliances and power groups to uphold the current model prevail beyond the evidence of the need for change, while those who defend a sustainable development model still seem unable to implement the proposed changes. Accentuated by the difficulty of perceiving the SDGs as going beyond sectoral policies, their implementation is terribly slow, and little progress has been made. The same argument holds for circular systems, whose rationality seems obvious to everyone.

Awareness of some of these barriers by identifying controversies permits actions that will speed up the transitions, such as the design of methods, criteria, indicators, and metrics to better understand and document the oppositions and uncertainties and facilitate the dialogue.

It is evident in this study that research and actions on these themes, many of them coming from "alternative" sectors, are insufficient to point out effective changes or widely divulge their findings. To overcome the two-fold oppositions and polarizations that favor procrastination, hamper transitions, and disrupt decision-making due to existing power games, we consider that an innovative articulation between initiatives on different levels is necessary, in which research could play a fundamental role.

\section{NOTE}

i)We are grateful for the contributions to the debates by the researchers Dr. Habiba Bouhamed Chaabouni, Dr. Philippe Mayaud, Dr. John Porter, and Dr. Martin Van Ittersum, as many of the ideas herein were discussed during the second half of 2018, in the first MAK!T cohor.

ii) MAK!IT ((Montpellier Advanced Knowledge Institute on Transitions) was created in early 2019, after debates with invited scientists and researchers with the aim of testing the controversial approach. It was based on a pilot controversy related to the priorities of the international agenda and that influenced, in a transversal way, the agricultural and food, environmental and health transitions, necessary to reach the Sustainable Development Goals.

iii) Between 2000 and 2012 the world lost 2.3 million square kilometers (230 million hectares) of forest cover - equivalent to 50 forest football fields lost every minute every day for 12 years. The countries with the greatest loss of forest cover are Russia, Brazil, Canada, the United States and Indonesia, according to Global Forest Watch.

\section{REFERENCES}

CALLON M., 1986. Éléments pour une sociologie de la traduction. La domestication des coquilles Saint-Jacques dans la Baie de Saint-Brieuc, l’Année sociologique 36.

CARON, P., FERRERO y de Loma-Osorio, G., NABARRO, D., HAINZELIN, E., GUILLOU et al. 2018. Food systems for sustainable development: Proposals for a profound four-part transformation. Agronomy for Sustainable Development, 38(4).

CARON P., 2020. From crisis to utopia: crafting new public-private articulation at territorial level to design sustainable food systems. Agriculture and Human Values. https://doi.org/10.1007/s10460-020-10065-1

CENTRO DE GESTÃO E ESTUDOS ESTRATÉGICOS. 2012. Economia verde para o desenvolvimento sustentável. Brasília, Distrito Federal. 
CHEVALLIER-LE GUYADER M.-F., GIREL M., 2015. Polémique, débat et controverse : retour sur une notion. In: Au coeur des controverses. Des sciences à l'action. C ACTES SUD/IHEST, 240 p. ISBN 978-2-330-05713-8.

DE BOER J.M., Van Ittersum M., 2018. Circularity in agricultural production. Mansholt lecture, Brussels, 2018. https://www.wur.nl/upload_mm/7/5/5/14119893-7258-45e6-b4d0-e514a8b6316a_Circularity-in-agricult ural-production-20122018.pdf

FOOD AND AGRICULTURE ORGANIZATION OF THE UNITED NATIONS (FAO), 2006. Livestock's long shadow: environmental issues and options. Roma,.

HERODOTE, 2015. Géopolitique de l'Agriculture. Institut Français de Géopolitique, Revue de Géographie et Géopolitique, ${ }^{\circ} 156$, premier trimestre,

HERODOTE, 2008. Les enjeux de la crise alimentaire mondiale. Instituto Français de Géopolitique, Revue de Géographie et Géopolitique, $\mathrm{n}^{\circ}$ 131, quatrième trimestre.

HENRICH BÖLL FOUNDATION. Atlas da Carne: fatos e números sobre os animais que comemos. Rio de Janeiro: Henrich Böll Foundation, 2015.

LOORBACH, D.; ROTMANS, J., 2002. Society in technology and technology in society, paper presented at the International Conference on Engineering Education for Sustainable Development (EESD), 24/25 October, Delft, The Netherlands.

HLPE. 2016. Sustainable agricultural development for food security and nutrition: what roles for livestock? A report by the High Level Panel of Experts on Food Security and Nutrition of the Committee on World Food Security. HLPE report 10. Rome. 140 pp. http://www.fao.org/3/a-i5795e.pdf.

HLPE. 2017. 2nd Note on Critical and Emerging Issues for Food Security and Nutrition. A note by the High Level Panel of Experts on Food Security and Nutrition of the Committee on World Food Security, Rome.

http://www.fao.org/fileadmin/user_upload/hlpe/hlpe_documents/Critical-Emerging-Issues-2016/HLPE_ Note-to-CFS_Critical-and-Emerging-Issues-2nd-Edition 27-April-2017.pdf

HLPE. 2019. Agroecological and other innovative approaches for sustainable agriculture and food systems that enhance food security and nutrition. A report by the High Level Panel of Experts on Food Security and Nutrition of the Committee on World Food Security. HLPE report 14. Rome. 163 pp. http://www.fao.org/3/ca5602en/ca5602en.pdf

JURGILEVICH, A.; BIRGE, T.; KENTALA-LEHTONEN, J.; KORHONEN-KURKI, K.; PIETIKÄINEN, J.; SAIKKU, L.; SCHÖSLER, H.. 2016. Transitions towards circular economy in the food system. https://www.mdpi.com/2071-1050/8/1/69

LATOUR B, 1987. Science in Action: How to Follow Scientists and Engineers through Society, Harvard University Press, 1987. (ISBN 0-674-79291-2)

LEMIEUX C., 2015. Logique des controverses : confinement, déconfinement, reconfinement. In: Au cœur des controverses. Des sciences à l'action. (C) ACTES SUD/IHEST, 240 p. ISBN 978-2-330-05713-8.)

MURPHY, S., BURCH, D., CLAPP, J. 2012. Cereal secrets. Oxford, UK, Oxfam.

MOTTET, A.; DE HAAN, C.; FAlCUCCIA, A.; TEMPIO, G.; OPIO, C.; GERBER, P., 2017. Livestock: On our plates or eating at our table? A new analysis of the feed/ food debate. Global Food Security, 14: 1-8. https://dx.doi.org/10.1016/j.gfs.2017.01.001

PNAS. 2015. Analysis and valuation on the health and climate change cobenefits of dietary change.

RASTOIN, J-L.; GHERSI, G. 2010. Concepts et méthodes, analyses et dynamiques. Versailles, Editions Quae. 
REGANOLD, J. P.; WACHTER, J. 2016. Organic agriculture in the twenty-first. Nature Plants, v. 2, article number 15221. jan.

SACHS, I. 2008. La Troisième Rive, À la Recherche de l'Écodévelopement. Paris: Bourin Éditeur.

STOCKHOLM RESILIENCE CENTRE, Stockholm University, Dr Marco Springmann and Martin Oxford, Programme on the Future of Food and the Nuffield Department of Population Health at the University of Oxford). https://www.stockholmresilience.org/

VEIGA, J. E. da. 2014. Amago da sustentabilidade. Revista Estudos Avançados, V. 28, No 82.

TRUFFER, B.; COENEN, L.. 2011. Environmental Innovation and Sustainability Transitions in Regional Studies. Studies Lecture, Version 1, 04/04/11, p. 1

THERY, H.; CARON, P.. 2019. Circulation, consommation mondiale des viandes et obésité : coïncidences ou co-incidences ?, Confins [En ligne], $40 \mid 2019$, mis en ligne le 13 juillet 2019. URL : http://journals.openedition.org/confins/20153, DOI: https://doi.org/10.4000/confins.20153

UNEP. 2010. Towards a green economy: pathways to sustainable development and poverty eradication a synthesis for policy makers. Disponível em www.unep.org/greeneconom.

WILLETT W, ROCKSTRO M.J, LOKEN B, SPRINGMANN M, LANG T, VERMEULEN S. et al. 2019. Food in the Anthropocene: the EAT-Lancet Commission on healthy diets from sustainable food systems The Lancet; Jan. https://doi.org/10.1016/S0140-6736 (18)31788-4

ZUINEN, N., GOUZEE, N.. 2010. Biocapacité et empreinte écologique des modes de viwe: des indicateurs pour la politique de développement durable ? Bureau fédéral du Plan : working paper 11-10, juin.

\section{SITES}

https://www.footprintnetwork.org/

http://www.foodpolicymilano.org/milan-urban-food-policy-pact/\#: :text=Il\%20Milan\%20Urban\%20Fo od $\% 20$ Policy $\% 20$ Pact $\% 20 \%$ C3\%A8\%20un,abitano $\% 20$ e $\% 20$ lavorano $\% 20$ oltre $\% 20470 \% 20$ milioni $\% 2$ 0di\%20persone

https://glad.umd.edu/projects/global-forest-watch

http://www.inpe.br

htpp://www.yeldgap.org 